\title{
LEAD AND ZINC EXTRACTION POTENTIAL OF TWO COMMON CROP PLANTS, HELIANTHUS ANNUUS AND BRASSICA NAPUS
}

\author{
MAHMOUD SOLHI ${ }^{1, *}$, HOSSAIN SHAREATMADARI ${ }^{2}$ \\ and MOHAMMAD A. HAJABBASI ${ }^{2}$ \\ ${ }^{1}$ Soil and Water Department, Isfahan Agricultural Research Center, Isfahan, Iran; ${ }^{2}$ Soil Science \\ Department, College of Agriculture, Isfahan University of Technology, Isfahan, Iran \\ (*author for correspondence, e-mail: msolhi@ag.iut.ac.ir, Tel.: +98-311-7753804, \\ Fax: +98-311-7757022)
}

(Received 4 March 2005; accepted 27 May 2005)

\begin{abstract}
Phytoextraction is a remediation technology that uses plants to remove heavy metals from soil. The success of a phytoextraction process depends on adequate plant yield (aerial parts) and high metal concentrations in plant shoots. A pot experiment was conducted to investigate the combination effects of plants [sunflower (Helianthus annuus) and canola (Brassica napus)] with soil treatments (manure, sulfuric acid and DTPA). Treatments, including two plants and seven soil treatments, which applied according to completely randomized factorial design with three replications. The largest shoot dry weight biomass production occurred in manure treatments for both plants. The maximum shoot concentrations of $\mathrm{Pb}$ and $\mathrm{Zn}$ were 234.6 and $1364.4 \mathrm{mg} \mathrm{kg}^{-1}$ respectively in three mmoles DTPA $\mathrm{kg}^{-1}$ treatment of sunflower. Furthermore the results showed that sunflower had a higher extracting potential for removal of $\mathrm{Pb}$ and $\mathrm{Zn}$ from polluted soil.
\end{abstract}

Keywords: accumulation, canola, lead, phytoextraction, sunflower, zinc

\section{Introduction}

Heavy metal contamination is an increasing worldwide environmental concern (Body et al., 1991). The main sources of heavy metals in the environment are industrial, agricultural and urban activities. Contamination of soil-water-plant system with heavy metals is a form of chemical environmental load which has health, economic and ecological importance (Alloway, 1995). Numerous studies have been conducted on remediation of heavy metal contaminated soil by employing thermal, chemical, physical and biological treatments, and significant progress has been made (Holden, 1989). These conventional methods are usually very expensive (Salt et al., 1995).

In recent years phytoextraction has been suggested by several authors as a green and low-cost technology to clean up metal polluted sites (Cunningham et al., 1995; Kumar et al., 1995; Jorgensen, 1993; McGrath et al., 1993). This technique uses the ability of certain plants to accumulate heavy metals in a high concentration in their aboveground parts. The success of a phytoextraction process depends on biomass production and metal concentration in plant shoots (Raskin et al., 1994). Results 
of several studies under greenhouse or growth chamber conditions indicated that some crops and hyperaccumulating species have the potential to remove metals from polluted soils (Chaney, 1997; Shen et al., 1997). Phytoextraction researches have been started using hyperaccumulators, like Thlaspi caerulescens, a member of the Brassicaceae family. Hyperaccumulators not only grow on high polluted soils, but also accumulate pollutants in a high concentration in their tissues (McGrath et al., 1993; Kumar et al., 1995). For instance, hydroponically grown T. caerulescens accumulated about $33600 \mathrm{mg} \mathrm{Zn} \mathrm{kg}^{-1}$ in shoots (Salt et al., 1995). Some hyperaccumulators like Ipomoea alpine and Haumaniastrum katangense could accumulate about $12300 \mathrm{mg} \mathrm{Cu} \mathrm{kg}^{-1}$ and $19800 \mathrm{mg} \mathrm{Zn} \mathrm{kg}^{-1}$ in their leaves, respectively (Baker and Walker, 1990). However, many of these species are slow growing and produce small amount of biomass thus, can not remove large quantities of heavy metals per unit of land area in a given period of time (Krueger et al., 1997). In contrast some plant species, producing a relatively large biomass, are capable of accumulating and tolerating moderate to high levels of heavy metals in their tissues. For instance, some varieties of corn (Zea mays L.), barley (Hordeum vulgaris L.) and ryegrass (Lolium perenne L.) have demonstrated significant heavy metal tolerance (Ebbs et al., 1997). On the other hand increasing and maintaining the bioavailability of heavy metals in soil solution, plays an important role in the phytoextraction process. Several chelating agents such as EDTA, DTPA, HEDTA, NTA and different organic acids have been used in pot and field experiments to enhance heavy metal uptake of plants (Kayser et al., 2000; Ebbs and Kochian, 1998; Blaylack et al., 1997; Huang and Cunningham, 1996). However in some cases in situ application of such chelates may pose the potential risk of water resources pollution. In this study the combination effects of plant types and soil treatments on enhancement of phytoextraction were investigated. For this purpose, $\mathrm{Pb}$ and $\mathrm{Zn}$ accumulating potential of aboveground tissues in sunflower and canola with application of several soil treatments (sulfuric acid, DTPA and composted manure) were compared.

\section{Materials and Methods}

\subsection{SiTE DESCRIPTION}

Lead and zinc polluted soils [Fine, Loamy, Mixed, Typic, Torrifluent (Soil Survey Staff, 1999)] were collected from surface around Bama mine at $20 \mathrm{~km}$ southwest of Isfahan city, central Iran (3598500N, 572000E, UTM, Zone 39) with the elevation of $1750 \mathrm{~m}$ and mean annual precipitation of $145 \mathrm{~mm}$.

\subsection{TREATMENTS AND STATISTICAL DESIGN}

The soil was incubated in the greenhouse at the temperature range of $18-25^{\circ} \mathrm{C}$ for 8 weeks. Soil moisture was raised to $80 \%$ of water holding capacity and maintained by periodical addition of water after weighing the pots. After incubation and reaching 
the soil to an equilibrium, the soil was air dried, grounded and passed a $2 \mathrm{~mm}$ sieve. Then $5.0 \mathrm{~kg}$ of air-dried soil was placed in each plastic pot and fertilized with a rate of $60.0 \mathrm{mg} \mathrm{N} \mathrm{kg}^{-1}$ dry soil as urea, $30.0 \mathrm{mg} \mathrm{P} \mathrm{kg}^{-1}$ as diammonium phosphate and $40.0 \mathrm{mg} \mathrm{K} \mathrm{kg}^{-1}$ as potassium sulphate. The experiment was conducted using a completely randomized factorial design containing three replications each with two plants and seven soil treatments. The treatments were: two levels of sulfuric acid [0.5 (S1) and $1.0(\mathrm{~S} 2)$ mmole acid $\mathrm{kg}^{-1}$ of pot dry soil], two levels of Diethylen Triamine Pentaacetic Acid [1.5 (D1) and 3 (D2) mmoles DTPA kg-1 of pot dry soil], two levels of composted manure [7.5 (M1) and 15 (M2) $\mathrm{g} \mathrm{kg}^{-1}$ of pot dry soil], and control (C). About 15 seeds of sunflower [Helianthus annuus (cv.hybride, hysun 25)] and canola [Brassica napus (cv.hybride, hyola 401)] were sown in separate pots for respective treatments. After germination, the seedlings were trimmed to five plants per pot and grown for 60 days. The DTPA and acid solution were applied with irrigation water where composted manure was mixed thoroughly with soil before sowing. Soil moisture was maintained at $60 \%$ of water holding capacity based on soil moisture characteristic curve, which was plotted at 10, 30, 50, 100, 300, 500, 1000 and $1500 \mathrm{kPa}$ (Klute, 1986).

\subsection{SAMPLES COLLECTION AND ANALYSES}

Plants were harvested by cutting the shoots at the soil surface and removing the roots from the pots. The shoots and roots were washed with tap water, rinsed with deionized water and dried at $80^{\circ} \mathrm{C}$ for $24 \mathrm{~h}$. The dry weight of shoots and roots were measured as dry biomass (DBM). Sub-samples of $2.0 \mathrm{~g}$ were digested in 6.0 $\mathrm{ml}$ of $65 \% \mathrm{HNO}_{3}, 2.0 \mathrm{ml} 2 \% \mathrm{H}_{2} \mathrm{O}_{2}$ and $2.0 \mathrm{ml}$ of distilled water, and heated at $100^{\circ} \mathrm{C}$ for $25 \mathrm{~m}$. The solution was then filtrated through Whatman filter paper No. 42. Soil samples were collected from each pot after harvesting and were prepared for chemical analysis. Soil $\mathrm{pH}$ measured in 1:2.5 soil distilled water suspensions. Clay, silt and sand percentage were determined by hydrometer method (Day, 1965). Organic carbon (OC) was determined using wet oxidation method (Walkley and Black, 1934). Total $\mathrm{Pb}$ and $\mathrm{Zn}$ concentrations in soil samples were extracted using a mixture of $\mathrm{HClO}_{4}, \mathrm{HF}$ and $\mathrm{HNO}_{3}$ (Pratt, 1965). Ten $\mathrm{ml}$ of concentrated nitric acid was added to 2.0 gram of soil and kept overnight. Three drops of concentrated $\mathrm{H}_{2} \mathrm{SO}_{4}$ and $10 \mathrm{ml} \mathrm{HF}$ were added to the samples and the temperature raised slowly up to $200{ }^{\circ} \mathrm{C}$. Fifteen $\mathrm{ml}$ of concentrated $\mathrm{HNO}_{3}, 2 \mathrm{ml}$ of concentrated $\mathrm{H}_{2} \mathrm{SO}_{4}$ and $5 \mathrm{ml}$ of $\mathrm{HClO}_{4}$ were added to solution and extracted through Whatman filter paper No. 42. DTPA Extractable concentrations of $\mathrm{Pb}$ and $\mathrm{Zn}$ were determined using the method of Lindsay and Norvel (1978). The extracting solution contains $0.005 \mathrm{M}$ DTPA, $0.01 \mathrm{M} \mathrm{CaCl} \cdot \mathrm{H}_{2} \mathrm{O}$ and $0.1 \mathrm{M}$ triethanolamine (TEA). Ten grams of airdried soil were placed to polyethylene bottle, $20 \mathrm{ml}$ of extractant was added and shaken for $2.0 \mathrm{~h}$. Then filtered through Whatman filter paper No. 42. The $\mathrm{Pb}$ and $\mathrm{Zn}$ concentration of soils and plants were measured using Flame Atomic Absorption Spectrophotometry (FAAS) Perkin Elmer model 2380. 


\subsection{Statistical ANALyses}

Statistical analyses were performed on log-transformed concentration (data were $\log$ normal). Regression analyses were performed with SAS software version 6.12. Analysis of variance (ANOVA) was performed using the GLM procedure (general linear model) of SAS 6.12, to compare treatment effects on heavy metal content in soil and plant tissues. If the $F$-value indicated significant difference $(p<0.05)$, mean comparison were carried out using Duncan test.

\section{Results and Discussion}

Some physicochemical properties of soil are summarized in Table I. The selected soil was clay loam, nonsaline, low organic carbon and rich in $\mathrm{Pb}$ and $\mathrm{Zn}$ inherited from mine parent material. The average $\mathrm{Pb}$ and $\mathrm{Zn}$ total concentrations of the soil were 1564.0 and $2739.0 \mathrm{mg} \mathrm{kg}^{-1}$, while DTPA extractable concentrations of $\mathrm{Pb}$ and $\mathrm{Zn}$ were 29.0 and $182.0 \mathrm{mg} \mathrm{kg}^{-1}$, respectively. Variation of DTPA Extractable $\mathrm{Pb}$ and $\mathrm{Zn}$ concentration during 8 weeks of incubation are shown in Figure 1.

TABLE I

Physicochemical properties of studied soil

\begin{tabular}{|c|c|c|c|c|c|c|c|c|c|}
\hline \multirow{2}{*}{$\begin{array}{l}\mathrm{EC}_{e} \\
\left(\mathrm{dS} \mathrm{m}^{-1}\right)\end{array}$} & \multirow[b]{2}{*}{$\mathrm{pH}$} & \multirow[b]{2}{*}{$\mathrm{OC}^{\mathrm{a}} \%$} & \multicolumn{4}{|c|}{$\mathrm{mg} \mathrm{kg}^{-1}$} & \multicolumn{3}{|c|}{$\mathrm{g} \mathrm{kg}^{-1}$} \\
\hline & & & Total $\mathrm{Pb}$ & DTPA Ext.Pb & Total Zn & DTPA Ext.Zn & Sand & Silt & Clay \\
\hline 1.8 & 7.3 & 1.08 & 1564.4 & 28.7 & 2738.6 & 181.7 & 250.0 & 360.0 & 390.0 \\
\hline
\end{tabular}

${ }^{a} \mathrm{OC}$ : Organic carbon.

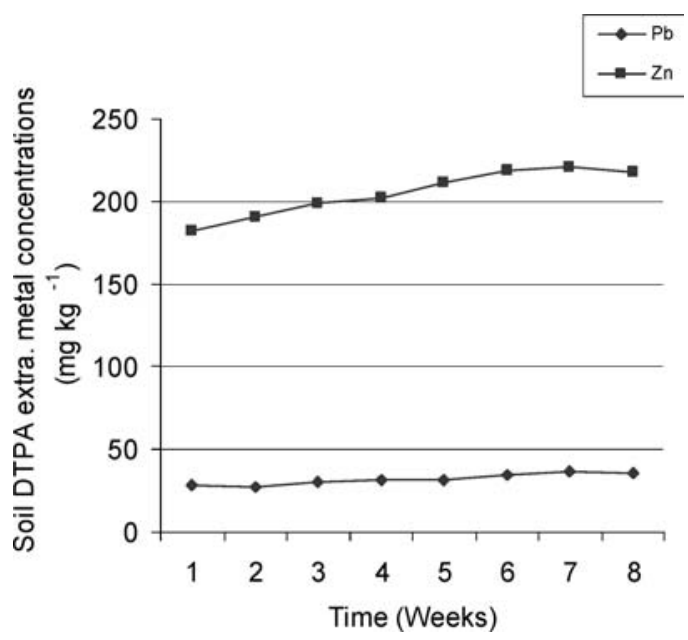

Figure 1. Variation of DTPA extractable metal concentrations during incubation time. 
Eight weeks incubation of soil resulted a gentle increase of DTPA Extractable concentrations of $\mathrm{Pb}$ and $\mathrm{Zn}$ and then produced an equilibrium in the soil with nearly constant levels of metal concentrations.

\subsection{EFFECTS OF TREATMENTS ON BIOMASS PRODUCTION}

The ANOVA analysis showed a significant $(p<0.05)$ difference for biomass production among the treatments (Table II). Both composted manure treatments (M1 and M2) increased shoot biomass of sunflower and canola significantly ( $p<$ $0.05)$. The largest shoot dry biomass production occurred in manure treatment both for sunflower (76.5 g per pot) and canola (46.7 g per pot). Composted manure improved physicochemical and biological properties of soil resulted a significant increment of plant growth (Paul, 1984). The least values of shoot dry biomass of sunflower and canola were found in the D2 treatment (Table II). Treating the soil with 3 mmoles DTPA $\mathrm{kg}^{-1}$ increased the metals availability thus phytotoxicity may inhibit plant growth and biomass reduction. Applying 1.5 mmoles DTPA kg-1 reduced dry biomass of canola by $24.0 \%$ but it had no significant effect on dry biomass of sunflower indicating sunflower was more tolerant than canola. Shen

TABLE II

Dry biomass (DBM) and dry biomass coefficient (DBMC) of sunflower and canola in different treatments

\begin{tabular}{llll}
\hline Plants & Treatments $^{\mathrm{a}}$ & DBM $(\mathrm{g})^{\mathrm{b}}$ & DBMC \\
\hline Sunflower & S1 & $67.0 \mathrm{~b}$ & 0.88 \\
& S2 & $64.2 \mathrm{~b}$ & 0.84 \\
& D1 & $65.1 \mathrm{~b}$ & 0.85 \\
& D2 & $64.1 \mathrm{~b}$ & 0.84 \\
& M1 & $73.8 \mathrm{a}$ & 0.96 \\
& M2 & $76.5 \mathrm{a}$ & 1.00 \\
& C & $65.7 \mathrm{~b}$ & 0.86 \\
& S1 & $37.0 \mathrm{~d}$ & 0.48 \\
& S2 & $35.6 \mathrm{~d}$ & 0.47 \\
& D1 & $28.5 \mathrm{de}$ & 0.37 \\
& D2 & $21.5 \mathrm{e}$ & 0.28 \\
& M1 & $43.3 \mathrm{c}$ & 0.57 \\
& M2 & $46.7 \mathrm{c}$ & 0.61 \\
& C & $36.2 \mathrm{~d}$ & 0.47 \\
\hline
\end{tabular}

${ }^{\text {a }}$ 1 and S2 stand for 0.5 and 1.5 mmoles acid $\mathrm{kg}^{-1}$ of pot soil, D1 and D2 stand for 1.5 and 3.0 mmoles DTPA $\mathrm{kg}^{-1}$ of pot soil, M1 and M2 stand for 7.5 and $15.0 \mathrm{~g} \mathrm{~kg}^{-1}$ of pot soil, and $\mathrm{C}$ for control.

${ }^{b}$ Values followed by the same letter within columns are not significantly different at $p<0.05$. 
(1997) reported that after $7 \mathrm{~d}$ of EDTA (3.0 mmole $\mathrm{kg}^{-1}$ ) application, dry matter yield of cabbage, hanelt, mung bean and wheat decreased significantly compared with those without EDTA treatment. Acid treatments did not show any significant change in biomass production of sunflower and canola.

\subsection{EFFECTS OF TREATMENTS ON Pb SHOOT AND ROOT CONCENTRATIONS OF PLANTS}

The ANOVA analysis showed significant differences in shoot and root $\mathrm{Pb}$ concentrations of sunflower and canola $(p<0.05)$. Maximum $\mathrm{Pb}$ concentrations were found in D2 treatment in shoot of sunflower, whereas for canola the maximum shoot $\mathrm{Pb}$ concentrations occurred in the D1 treatments (Table III). Compared to control, $\mathrm{Pb}$ shoot concentrations of sunflower increased by $1.10,1.60$ and 2.00 fold in manure, acid and DTPA treatments, respectively. The values for canola were 1.50, 1.70 and 2.26 fold (Table III). Although the increasing rate of $\mathrm{Pb}$ concentrations in shoot of canola was more than sunflower but the absolute shoot $\mathrm{Pb}$ concentrations of sunflower were higher than that of canola.

Root $\mathrm{Pb}$ concentrations of sunflower increased 1.20, 1.70 and 1.90 fold in manure, acid and DTPA treatments respectively compared to control. These values

TABLE III

Soil and plant $\mathrm{Pb}$ concentrations $\left(\mathrm{mg} \mathrm{kg}^{-1}\right)$

\begin{tabular}{lllll}
\hline Plants & Treatments $^{\mathrm{a}}$ & Soil DTPA Extr.Pb $^{\mathrm{b}}$ & Shoot Pb & Root Pb \\
\hline Sunflower & S1 & $68.8 \mathrm{~b}$ & $137.9 \mathrm{~b}$ & $369.3 \mathrm{~b}$ \\
& S2 & $94.4 \mathrm{a}$ & $230.7 \mathrm{a}$ & $451.0 \mathrm{a}$ \\
& D1 & $89.6 \mathrm{a}$ & $230.4 \mathrm{a}$ & $450.3 \mathrm{a}$ \\
& D2 & $94.4 \mathrm{a}$ & $234.6 \mathrm{a}$ & $466.9 \mathrm{a}$ \\
& M1 & $58.0 \mathrm{bc}$ & $127.6 \mathrm{~b}$ & $291.5 \mathrm{bc}$ \\
& M2 & $59.4 \mathrm{bc}$ & $128.1 \mathrm{~b}$ & $301.1 \mathrm{bc}$ \\
Canola & C & $32.7 \mathrm{c}$ & $115.5 \mathrm{~b}$ & $237.6 \mathrm{c}$ \\
& S1 & $64.7 \mathrm{~b}$ & $79.0 \mathrm{bc}$ & $251.1 \mathrm{c}$ \\
& S2 & $60.3 \mathrm{bc}$ & $83.6 \mathrm{bc}$ & $204.3 \mathrm{bc}$ \\
& D1 & $95.5 \mathrm{a}$ & $109.1 \mathrm{~b}$ & $332.7 \mathrm{bc}$ \\
& D2 & $90.3 \mathrm{a}$ & $106.5 \mathrm{~b}$ & $347.5 \mathrm{bc}$ \\
& M1 & $56.9 \mathrm{bc}$ & $79.4 \mathrm{bc}$ & $205.4 \mathrm{bc}$ \\
& M2 & $55.0 \mathrm{bc}$ & $65.4 \mathrm{bc}$ & $184.7 \mathrm{~d}$ \\
& $\mathrm{C}$ & $38.9 \mathrm{c}$ & $47.7 \mathrm{c}$ & $165.5 \mathrm{~d}$ \\
\hline
\end{tabular}

${ }^{\text {a }} \mathrm{S} 1$ and S2 stand for 0.5 and 1.5 mmoles acid $\mathrm{kg}^{-1}$ of pot soil, D1 and D2 stand for 1.5 and 3.0 mmoles DTPA $\mathrm{kg}^{-1}$ of pot soil, M1 and M2 stand for 7.5 and $15.0 \mathrm{~g} \mathrm{~kg}^{-1}$ of pot soil, and $\mathrm{C}$ for control.

${ }^{\mathrm{b}}$ Values followed by the same letter within columns are not significantly different at $p<0.05$. 
for canola were 1.20, 1.40 and 2.00 fold (Table III). The greatest increasing rate of shoot and root Pb concentrations occurred in DTPA treatments (D1 and D2) both for sunflower and canola $(2.00,2.26,1.90$ and 2.00 fold).

\subsection{EFFECTS OF TREATMENTS ON Zn SHOOT AND ROOT CONCENTRATIONS OF PLANTS}

The ANOVA analysis showed significant differences in shoot and root $\mathrm{Zn}$ concentrations of sunflower and canola $(p<0.05)$. The maximum $\mathrm{Zn}$ concentrations were found in D2 treatment in shoot of sunflower and canola (Table IV). Zinc concentrations in shoot of sunflower increased 1.87, 2.04 and 2.80 fold in manure, acid and DTPA treatments in comparison with control. These values for canola were 1.30, 1.46 and 1.78 fold (Table IV) which were lower than that of sunflower significantly $(p<0.05)$.

Root $\mathrm{Zn}$ concentrations of sunflower increased 1.30, 1.50 and 1.80 fold in manure, acid and DTPA treatments where the values for canola were 1.40, 1.70 and 2.25 fold (Table IV). In the case of $\mathrm{Zn}$ also the greatest increasing rate of $\mathrm{Zn}$ concentration in shoots and roots of sunflower and canola were observed in DTPA treatments (D1 and D2) $(2.80,1.78,1.80$ and 2.25 fold).

TABLE IV

Soil and plant $\mathrm{Zn}$ concentrations $\left(\mathrm{mg} \mathrm{kg}^{-1}\right)$

\begin{tabular}{llllc}
\hline Plants & Treatments $^{\mathrm{a}}$ & Soil DTPA Extr.Zn & Shoot Zn & Root Zn \\
\hline Sunflower & S1 & $323.2 \mathrm{~b}$ & $937.3 \mathrm{~b}$ & $810.3 \mathrm{~b}$ \\
& S2 & $371.1 \mathrm{ab}$ & $958.8 \mathrm{~b}$ & $851.2 \mathrm{~b}$ \\
& D1 & $402.8 \mathrm{a}$ & $1231.7 \mathrm{a}$ & $1082.2 \mathrm{a}$ \\
& D2 & $428.7 \mathrm{a}$ & $1364.4 \mathrm{a}$ & $1250.9 \mathrm{a}$ \\
& M1 & $292.6 \mathrm{bc}$ & $879.4 \mathrm{bc}$ & $729.7 \mathrm{bc}$ \\
& M2 & $286.4 \mathrm{bc}$ & $851.2 \mathrm{bc}$ & $739.4 \mathrm{bc}$ \\
Canola & C & $146.2 \mathrm{~d}$ & $463.2 \mathrm{e}$ & $432.6 \mathrm{~d}$ \\
& S1 & $319.1 \mathrm{~b}$ & $648.2 \mathrm{c}$ & $426.7 \mathrm{~d}$ \\
& S2 & $343.7 \mathrm{ab}$ & $628.0 \mathrm{c}$ & $487.7 \mathrm{~d}$ \\
& D1 & $393.7 \mathrm{a}$ & $735.2 \mathrm{bc}$ & $551.9 \mathrm{~cd}$ \\
& D2 & $389.1 \mathrm{a}$ & $817.7 \mathrm{bc}$ & $668.1 \mathrm{c}$ \\
& M1 & $278.2 \mathrm{c}$ & $568.1 \mathrm{~cd}$ & $394.4 \mathrm{de}$ \\
& M2 & $272.3 \mathrm{c}$ & $568.2 \mathrm{~cd}$ & $353.4 \mathrm{de}$ \\
& C & $151.9 \mathrm{~d}$ & $436.7 \mathrm{~d}$ & $271.5 \mathrm{e}$ \\
\hline
\end{tabular}

${ }^{\mathrm{a}} \mathrm{S} 1$ and S2 stand for 0.5 and 1.5 mmoles acid $\mathrm{kg}^{-1}$ of pot soil, D1 and D2 stand for 1.5 and 3.0 mmoles DTPA kg ${ }^{-1}$ of pot soil, M1 and M2 stand for 7.5 and $15.0 \mathrm{~g} \mathrm{~kg}^{-1}$ of pot soil, and $\mathrm{C}$ for control.

${ }^{b}$ Values followed by the same letter within columns are not significantly different at $p<0.05$. 
The results showed that DTPA treatments increased the supply of $\mathrm{Pb}$ and $\mathrm{Zn}$ for root uptake of sunflower and canola by increasing metal availability in soil. Making the metals available, DTPA treatments were more efficient than the other treatments, so that shoot and root $\mathrm{Pb}$ and $\mathrm{Zn}$ concentrations were significantly higher than manure and acid treatments (Tables III and IV). In addition $\mathrm{Pb}$ and $\mathrm{Zn}$ concentrations in shoot and root of sunflower were more than canola for all treatments, showing a higher potential for metals removal. Lombi et al. (2001) reported that using of EDTA in two soils (French and UK soils) increased the concentrations of $\mathrm{Cd}, \mathrm{Cu}$ and $\mathrm{Zn}$ in the root of Thlaspi caerulescens by one to three fold as compared to control. Application of EDTA had no significant effect on the concentrations of metals in the shoot except for Zn which showed a 50\% increase in the UK soil.

\subsection{SOIL AND PLANT SHOOT METAL RELATIONSHIPS}

The metal concentrations of plant shoots had a positive linear correlation with soil DTPA extractable metal concentrations (Figure 2). The relationship between $\mathrm{Pb}$ and $\mathrm{Zn}$ DTPA extractable concentrations in soil and $\mathrm{Pb}$ and $\mathrm{Zn}$ shoots of sunflower and canola were as follows $(n=24)$ :

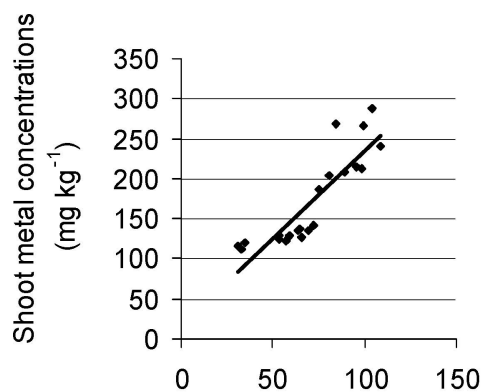

(a)

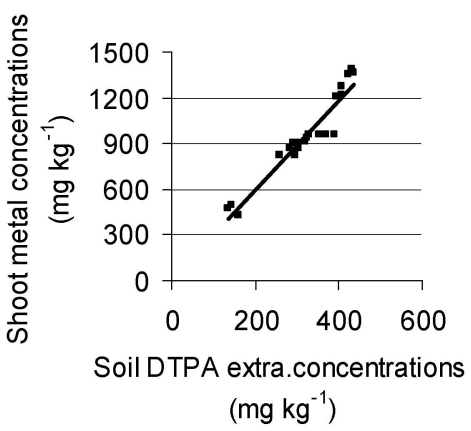

(c)

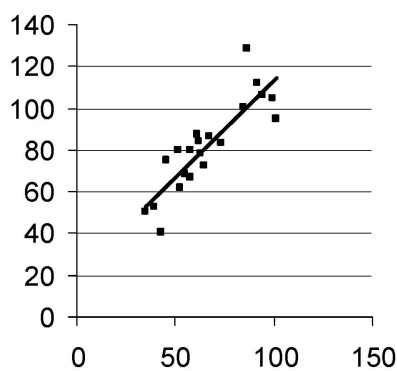

(b)

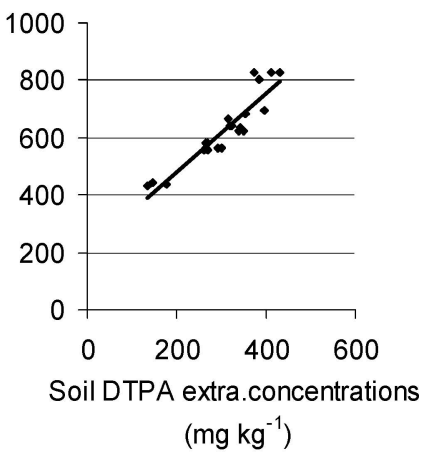

(d)

Figure 2. Correlation between soil DTPA extractable $\mathrm{Pb}$ and shoot $\mathrm{Pb}$ concentration of sunflower (a) and canola (b), correlation between soil DTPA extractable $\mathrm{Zn}$ and shoot $\mathrm{Zn}$ concentration of sunflower (c) and canola (d). 
For sunflower: $(P<0.01)$

$$
\begin{aligned}
& \text { Shoot }_{\mathrm{Pb}}=2.1896 \text { Soil }_{\mathrm{DTPA}} \text { Extra.Pb } \\
& \text { Shoot }_{\mathrm{Zn}}=2.9279 \text { Soil }_{\mathrm{Zn} \text { DTPA Extra.Zn }}+13.589, \quad R^{2}=0.7697 \text { [Figure 2(a)] } \\
& R^{2}=0.9191 \text { [Figure 2(b) }
\end{aligned}
$$

For canola $(P<0.01)$

$$
\begin{aligned}
& \text { Shoot }_{\mathrm{Pb}}=0.9329 \text { Soil }_{\text {DTPAExtra.Pb }}+20.038, \quad R^{2}=0.7425 \text { [Figure 2(c)] } \\
& \text { Shoot }_{\mathrm{Zn}}=1.3757 \text { Soil }_{\mathrm{ZnDTPAExtra.Zn}}+206.7, \quad R^{2}=0.8580 \text { [Figure 2(d)] }
\end{aligned}
$$

Stronger correlations existed between $\mathrm{Zn}$ concentrations in soil and shoots for both canola and sunflower.

Wenger et al. (2002) stated that in Zea mays shoot $\mathrm{Zn}$, linearly increased to about $1400 \mathrm{mg} \mathrm{kg}^{-1}$ dry weight as $\mathrm{NaNO}_{3}$-extractable $\mathrm{Zn}$ concentration in the soil increased to about $60 \mathrm{mg} \mathrm{kg}^{-1}$. Lehoczky (1996) also found a positive linear correlation between DTPA extractable $\mathrm{Cd}$ and $\mathrm{Zn}$ of soil with $\mathrm{Cd}$ and $\mathrm{Zn}$ concentration of upper plant parts.

\subsection{Pb UPTAKE}

Lead shoot/root ratios of sunflower were significantly greater than canola in all treatments (Table $\mathrm{V}$ ) that shows less resistance in translocation of $\mathrm{Pb}$ from root toward shoot in sunflower. Although Lombi et al. (2001) indicated that using EDTA can efficiently overcome the diffusion limitation of metals to root surface and resulting a lower $\mathrm{Pb}$ shoot/root ratio but our results showed that these ratios are small in all treatments including control for canola. Therefore the small shoot/root ratios in canola can not merely be related to the chelating agents.

Lead soil plant transfer coefficient (SPTC) which is defined as the ratio of shoot metal concentrations to the background soil total concentration was shown in Table V. SPTC of sunflower were about two times as much as canola's, indicating sunflower can extract more $\mathrm{Pb}$ than canola per kg of dry mass. Metal removal potential of accumulators is greatly related to the biomass production and metal concentration of aboveground tissues, therefore in this study shoot dry biomass also was considered. In this regard, uptake index (UI) which is obtained by multiplying of shoot dry biomass coefficient by shoot metal concentration, was recommended. Dry biomass coefficient (DBMC) also is defined as ratio of shoot dry biomass of a specific treatment to the maximum value of dry biomass among all treatments (Huang et al., 1997). UI is a relative criteria having the capability of ranking the treatments based on their respective metal removal. The larger metal UI, the higher potential of metal removal.

The largest amount of $\mathrm{Pb}$ UI was obtained for sunflower in D2 treatment (196.0) while for canola (45.0) obtained in M1 treatment (Table V). Therefore the most 
TABLE V

$\mathrm{Pb}$ shoot/root ratio, soil plant transfer coefficient (SPTC) and uptake index (UI)

\begin{tabular}{lllll}
\hline Plants & Treatments $^{\mathrm{a}}$ & Pb shoot/root ratio & Pb SPTC & Pb UI \\
\hline Sunflower & S1 & 0.37 & 0.09 & 120.72 \\
& S2 & 0.51 & 0.15 & 193.56 \\
& D1 & 0.51 & 0.15 & 195.88 \\
& D2 & 0.50 & 0.15 & 196.45 \\
& M1 & 0.44 & 0.08 & 123.09 \\
Canola & M2 & 0.43 & 0.08 & 128.10 \\
& C & 0.49 & 0.07 & 99.21 \\
& S1 & 0.31 & 0.05 & 38.21 \\
& S2 & 0.41 & 0.05 & 38.96 \\
& D1 & 0.33 & 0.07 & 40.70 \\
& D2 & 0.31 & 0.07 & 29.94 \\
& M1 & 0.39 & 0.05 & 44.92 \\
& M2 & 0.35 & 0.04 & 39.90 \\
& C & 0.29 & 0.03 & 22.56 \\
\hline
\end{tabular}

${ }^{\mathrm{a}} \mathrm{S} 1$ and $\mathrm{S} 2$ stand for 0.5 and 1.5 mmoles acid $\mathrm{kg}^{-1}$ of pot soil, D1 and D2 stand for 1.5 and 3.0 mmoles DTPA kg ${ }^{-1}$ of pot soil, M1 and M2 stand for 7.5 and $15.0 \mathrm{~g} \mathrm{~kg}^{-1}$ of pot soil, and $\mathrm{C}$ for control.

efficient treatment for Pb removal was 3 mmoles DTPA $\mathrm{kg}^{-1}$ (D2) with sunflower. The $\mathrm{Pb}$ UI of canola in D2 treatment was smaller than values observed for acid treatments (Table V). The reason may be metal phytotoxicity in D2 treatments which resulted a noticeable decline in dry biomass production of canola.

\subsection{Zn UPTAKE}

The maximum value of $\mathrm{Zn}$ shoot/root ratio for sunflower was 1.21 in M1 treatment and for canola was 1.61 in M2 and control. Zn shoot/root ratios for canola were greater than sunflower in all treatments (Table VI) indicating that $\mathrm{Zn}$ translocation from root toward shoot in canola was greater than sunflower. Although the $\mathrm{Zn}$ shoot/root ratios of canola was more than sunflower but the absolute $\mathrm{Zn}$ concentrations in root and shoot of sunflower were more than canola. The maximum values of Zn SPTC in sunflower and canola were found in D2 treatment (Table VI). Zinc SPTC in sunflower were significantly higher than canola in all treatments $(p<0.05)$ showing a higher accumulating potential of $\mathrm{Zn}$ in upper parts of sunflower. The high $\mathrm{Zn}$ concentrations in sunflower at D2 treatment are in good agreement with findings of Kayser et al. (2000) in a greenhouse study where Nicotiana tabacum and Zea mays were found to take up a great amount of $\mathrm{Zn}$ when metal solubility in soil was enhanced by addition of elementary sulfur. 
TABLE VI

Zn shoot/root ratio, soil plant transfer coefficient (SPTC) and uptake index (UI)

\begin{tabular}{llllr}
\hline Plants & Treatments $^{\mathrm{a}}$ & Zn shoot/root ratio & Zn SPTC & Pb UI \\
\hline Sunflower & S1 & 1.16 & 0.34 & 820.52 \\
& S2 & 1.13 & 0.35 & 804.44 \\
& D1 & 1.14 & 0.45 & 1047.15 \\
& D2 & 1.09 & 0.50 & 1142.50 \\
& M1 & 1.21 & 0.32 & 848.33 \\
Canola & M2 & 1.15 & 0.31 & 851.20 \\
& C & 1.07 & 0.17 & 397.87 \\
& S1 & 1.52 & 0.24 & 313.51 \\
& S2 & 1.29 & 0.23 & 292.68 \\
& D1 & 1.33 & 0.27 & 274.24 \\
& D2 & 1.22 & 0.30 & 229.88 \\
& M1 & 1.44 & 0.21 & 321.40 \\
& M2 & 1.61 & 0.21 & 334.03 \\
& C & 1.61 & 0.16 & 206.56 \\
\hline
\end{tabular}

${ }^{a} \mathrm{~S} 1$ and S2 stand for 0.5 and 1.5 mmoles acid $\mathrm{kg}^{-1}$ of pot soil, D1 and D2 stand for 1.5 and 3.0 mmoles DTPA kg-1 of pot soil, M1 and M2 stand for 7.5 and $15.0 \mathrm{~g} \mathrm{~kg}^{-1}$ of pot soil, and $\mathrm{C}$ for control.

Calculated Zn UIs for sunflower were much greater than canola's (Table VI). The maximum Zn UI for sunflower was found in D2 treatment (1142.0) while the maximum Zn UI of canola was found in M2 treatment (334.0). The most efficient treatment for $\mathrm{Zn}$ removal also was 3 mmoles DTPA $\mathrm{kg}^{-1}$ treatment (D2) with sunflower.

\section{Conclusion}

This study was launched to evaluate the effects of different levels of DTPA, sulfuric acid, manure and control on biomass production and $\mathrm{Zn}$ and $\mathrm{Pb}$ accumulation in plant tissues. The species showed different response due to treatment changes, such that the maximum aerial biomass obtained in M2 treatment both for canola and sunflower. The maximum $\mathrm{Pb}$ and $\mathrm{Zn}$ concentrations were found in $\mathrm{D} 2$ treatment for sunflower and canola where the minimum concentrations of $\mathrm{Zn}$ and $\mathrm{Pb}$ were found in control. Metal concentrations in plant shoots had a positive linear correlation with soil DTPA extractable method of analyzing. When sunflower was treated with 3 mmoles of DTPA kg-1 soil, the most efficient combination of plant, treatment for $\mathrm{Pb}$ and $\mathrm{Zn}$ extraction was observed. 


\section{Acknowledgements}

This work was a part of $\mathrm{PhD}$ dissertation at the Department of Soil Science, Isfahan University of Technology and supported by Soil and Water Department of Isfahan Agricultural Research Center. We are grateful to Dr. A. A. Shahabi and Dr. S. Ismaeelkhanian for their valuable help. The contribution of the reviewers is appreciated.

\section{References}

Alloway, B. J.: 1995, Heavy Metals in Soils, 2nd ed. Blackie Academic and Professional, London, England.

Baker, A. J. M. and Walker, P. L.: 1990, 'Ecophysiology of metal uptake by tolerant plants', in Shaw, J. A. (ed.), Heavy Metal Tolerance in Plants: Evolutionary Aspects; CRC, Boca Raton, FL, pp. 157-177.

Blaylock, M, J., Salt, D. E., Dushenkov, S, O., Gussman, C., Kapulnik,Y., Ensley, B. D. and Raskin, I.: 1997, 'Enhanced accumulation of Pb in Indian mustard by soil applied chelating agents', Environ. Sci. Technol. 31, 860-865.

Body, P. E., Dolan, P. R. and Mulcahy, D. E.: 1991, 'Environmental lead, a review', Crit. Rev. Environ. Control 20, 299-310.

Chaney, R. L., Malik, M., Li, Y. M., Brown, S. L., Brewer, E. P., Angle, J. S. and Baker, A. J. M.: 1997, 'Phytoremediation of soil metals', Curr. Opin. Biotechnol. 8, 279-284.

Cunningham, S. C., Berti, W. R. and Huang, J. W.: 1995, 'Phytoremediation of contaminated soils', TIBTECH 13, 393-397.

Day, P. R.: 1965, 'Particle fractionation and particle size analysis', in Method of Soil Analysis, part 1. (Ed.C.A). pp. 545-565.

Ebbs, S. D., Lasat, M. M., Brady, D. J., Cornish, J., Gordon, R. and Kochian, L.V.: 1997, 'Phytoextraction of cadmium and zinc from a contaminated soil', J. Environ. Qual. 26, 1424-1430.

Ebbs, S. D. and Kochian, L. V.: 1998, 'Phytoextraction of Zinc by Oat (Avena sativa), barely (Hordeum vulgaris) and Indian mustard (Brassica junceae)', Environ. Sci. Technol. 32(6), 802-806.

Holden, T.: 1989, How to Select Hazardous Waste Treatment Technologies for Soils and Sludges: Alternative, Innovative, and Emerging Technologies, Noyes data corporation, Park Ridge, NJ.

Huang, J. W. and Cunningham, S. D.: 1996, 'Lead phytoexraction: Species variation in lead uptake and translocation', New Phytol. 134, 75-34.

Huang, J. W., Chen, J., Berti, W. B. and Cunningham, S. D.: 1997, 'Phytoexraction of leadcontaminated soils: Role of synthetic in lead phytoextraction', Environ. Sci. Technol. 31, 800805.

Jorgensen, S. E.: 1993, 'Removal of heavy metals from compost and soil by ecotechnological methods', Ecological Engineering 2, 89-100.

Kayser, A., Wenger, K., Attinger, W., Felix, H. R., Gupta, S. K. and Schullin, R.: 2000, 'Enhancement of phytoextraction of $\mathrm{Zn}, \mathrm{Cd}$ and $\mathrm{Cu}$ from calcareous soil: The use of NTA and sulphur amendments', Environ. Sci. Technol.

Klute, A.: 1986, 'Water retention: Laboratory methods', in A. Klute (ed.), Method of Soil Analysis, Soil Science Society of America, Madison, WI, USA, pp. 635-662.

Krueger, E. L., Anderson, T. A. and Coats, J. R.: 1997, Phytoremediation of Soil and Water Concentrations, Symp. series 664; ACS, Washington, DC.

Kumar, P. B. A. N., Dushenkov, V., Motto, H. and Raskin, I.: 1995, 'Phytoextraction: The use of plants to remove heavy metals from soils', Environ. Sci. Technol. 29, 1232-1238. 
Lehoczky, E., Szabados, I. and Marth, P.: 1996, 'Cd content of plants as affected by soil Cd concentration. Commun', Soil. Sci. Plant Analysis. 27, 1765-1777.

Lindsay, W. L. and Norvell, W. A.: 1978, 'Development of a DTPA soil test for zinc, iron, manganase and copper', Soil Sci. Soc. Am. J. 42, 421-428.

Lombi, E., Zhao, F. J., Dunham, S. J. and McGrath, S. P.: 2001, 'Phytoremediation of heavy metalcontaminated soils: Natural hyperaccumulation versus chemically enhanced phytoextraction', J. Environ. Qual. 30, 1919-1926.

McGrath, S. P.: 1988, 'Phytoextraction for soil remediation', in R. R. Brooks (ed.), Plants that Hyperaccumulate Heavy Metals: Their Role in Phytoremediation, Microbiology, Archeology, Mineral Exploration and Phytominig', CAB International, Wallingford, Oxon, UK, pp. 261-287.

McGrath, S. P., Sidoli, M. D., Baker, A. J. M. and Reeves, R. D.: 1993, 'The potential for the use of metal-accumulating plants for the in situ decontamination of metal polluted soils', in H. J. P. Eijsackers and T. Hamers (eds.), Integrated Soil and Sediment Research: A Basis for Proper Protection. Kluwer Academic Publishers, Dordrecht, The Netherlands, pp. 673-676.

Paul, E. A.:1984, 'Dynamics of organic matter soils', Plant Soil 76, 275-285.

Pratt, P. F.: 1965, 'Digestion with hydrofluoric and perchloric acid for total potassium and sodium', in C. A. Black (ed.), Methods of Soil Analysis, Part 2, pp. 1019-1021.

Raskin, I., Kumar, P. B. N. A., Dushenkov, V. and Salt, D. E.: 1994, 'Bioconcentration of heavy metals by plants', Curr. Opin. Biotechnol. 5, 285-290.

Robinson, B. H., Leblanc, M., Petit, D., Brooks, R. R., Kirkman, J. H. and Gregg, P. E. H.: 1988, 'The potential of Thlaspi caerulescens for phytoremediation ofcontaminated soils', Plant and Soil 203, $47-56$.

Salt, D. E., Blaylock, M., Kumar, N. P. B. A., Dushenkov, V., Ensley, B. D., Chet, I. and Raskin, I.: 1995, 'Phytoremediation: A novel strategy for the removal of toxic elements from the environment using plants', Biotechnology 13, 468-475.

Shen, Z. G., Zhao, F. J. and McGrath, S. P.: 1997, 'Uptake and transport of zinc in the hyperaccumulator Thlaspi caerulescens and nonhyperaccumulator Thlaspi ochroleucum', Plant Cell Environ. 20, 898-906.

Soil Survey Staff: 1999, Soil Taxonomy: A Basic System of Soil Classification for Making and Interpreting. Soil Surveys, 2nd edn. Agric. Handbook, Vol. 436. U.S. Govt. print. Office, Washington, DC, 869 pp.

Walkley, A. and Black, C. A.: 1934, 'An examination of the Degtareff method for determining soil organic matter and a proposed modification of the chromic acid titration', Method. Soil. Sci. 37, 29-38.

Wenger, K., Gupta, S. K., Furrer. G. and Schulin, R.: 2002, 'Zinc extraction potential of two common crop plants, Nicotiana tabacum and Zea mays', Plant and Soil 242, 217-225. 